\title{
Call for a collaborative management at Matang Mangrove Forest Reserve, Malaysia: An assessment from local stakeholders' view point
}

\author{
Columba Martínez-Espinosa ${ }^{\mathrm{a}, \mathrm{b}, *}$, Pieter Wolfs $^{\mathrm{b}, \dagger}$, Katherine Vande Velde ${ }^{\mathrm{a}}$, \\ Behara Satyanarayana $^{\mathrm{a}, \mathrm{e}, 1}$, Farid Dahdouh-Guebas ${ }^{\mathrm{a}, \mathrm{b}, 1}$, Jean Hugé $\mathrm{e}^{\mathrm{a}, \mathrm{b}, \mathrm{c}, \mathrm{d}, \mathrm{f}, 1}$ \\ ${ }^{\mathrm{a}}$ Laboratory of Systems Ecology and Resource Management, Department of Organism Biology, Faculty of Sciences, Université Libre de Bruxelles - ULB, B-1050 Brussels, \\ Belgium \\ ${ }^{\mathrm{b}}$ Laboratory of Plant Biology and Nature Management, Ecology and Biodiversity, Vrije Universiteit Brussel - VUB, B-1050 Brussels, Belgium \\ ${ }^{\mathrm{c}}$ Centre for Sustainable Development, Ghent University, B-9000, Gent, Belgium \\ ${ }^{\mathrm{d}}$ Belgium Centre for Environmental Science, Hasselt University, BE3500, Hasselt, Belgium \\ ${ }^{\mathrm{e}}$ Mangrove Research Unit (MARU), Institute of Oceanography and Environment (INOS), Universiti Malaysia Terengganu - UMT, 21030, Kuala Nerus, Terengganu, \\ Malaysia \\ ${ }^{\mathrm{f}}$ Open University of the Netherlands, Valkenburgerweg 177, 6419AT, Heerlen, the Netherlands
}

\section{A R T I C L E I N F O}

\section{Keywords:}

Mangrove management

Local-population perception

Stakeholder involvement

Forest management

Socio-ecological system

Ecosystem services

\begin{abstract}
A B S T R A C T
Effective management of a socio-ecological system (SES) requires a good understanding of: (i) ecosystem functionality, (ii) interactions between social and ecological units, and (iii) stakeholder perceptions and activities. Matang Mangrove Forest Reserve (MMFR) covering 40,200 ha in Peninsular Malaysia is under silvicultural management (with a 30-year forest rotation cycle) for charcoal and timber production since 1902.

The aim of this study is to assess the perceptions of (select) local stakeholders on the ongoing mangrove management of MMFR. Earlier, Huge et al. (2016), using Q methodology, identified three main shared perceptions, called discourses: (1) Optimization- 'keep up the good work, but keep improving', (2) Change for the better- 'ecotourism \& participatory management for sustainability', and (3) Continuity - 'business as usual is the way to go'. The current study is a follow-up to Huge et al. (2016) and reports on a survey which assessed the degree of support of the local stakeholders towards those three management discourses. The core statements of each discourse were presented as questions and then ranked by the participants.

Based on the findings of the survey, the local stakeholders were clustered into three main working categories: (i) charcoal and timber workers, (ii) fishermen and (iii) service providers. The interviews held with 114 stakeholders indicated that discourse (2) 'change for the better' is the most popular (supported by $72 \%$ of the participants) regardless of the stakeholders' working category. This discourse voices the involvement of local people in decision making, adopts participatory management, and encourages diverse mangrove-based economic activities beyond mere charcoal and timber production.

Single-use management (focusing only on maximising charcoal and timber yields) was perceived as not equitably benefiting all local stakeholders.

The insights of this study can guide the managers of Matang Mangrove Forest Reserve to improve the sustainability and the local support base for the existing mangrove management regime, e.g. by promoting diverse livelihood options for the local stakeholders.
\end{abstract}

\section{Introduction}

\subsection{Mangrove forests and their ecosystem services}

Mangrove ecosystems are consensually defined as "woody plants that grow in tropical and subtropical latitudes along the land-sea interface, bays, estuaries, lagoons, and backwaters. These plants and their associated organisms constitute a "mangrove forest community" or "mangal", while "mangal" and its associated abiotic factors constitute the "mangrove ecosystem" (Mukherjee et al., 2014a).

\footnotetext{
* Corresponding author.

E-mail address: columba.mar.es@gmail.com (C. Martínez-Espinosa).

${ }^{1}$ Co-last authors.

${ }^{\dagger}$ Deceased author.
} 
Matang Mangrove Forest Reserve -Social Ecological System

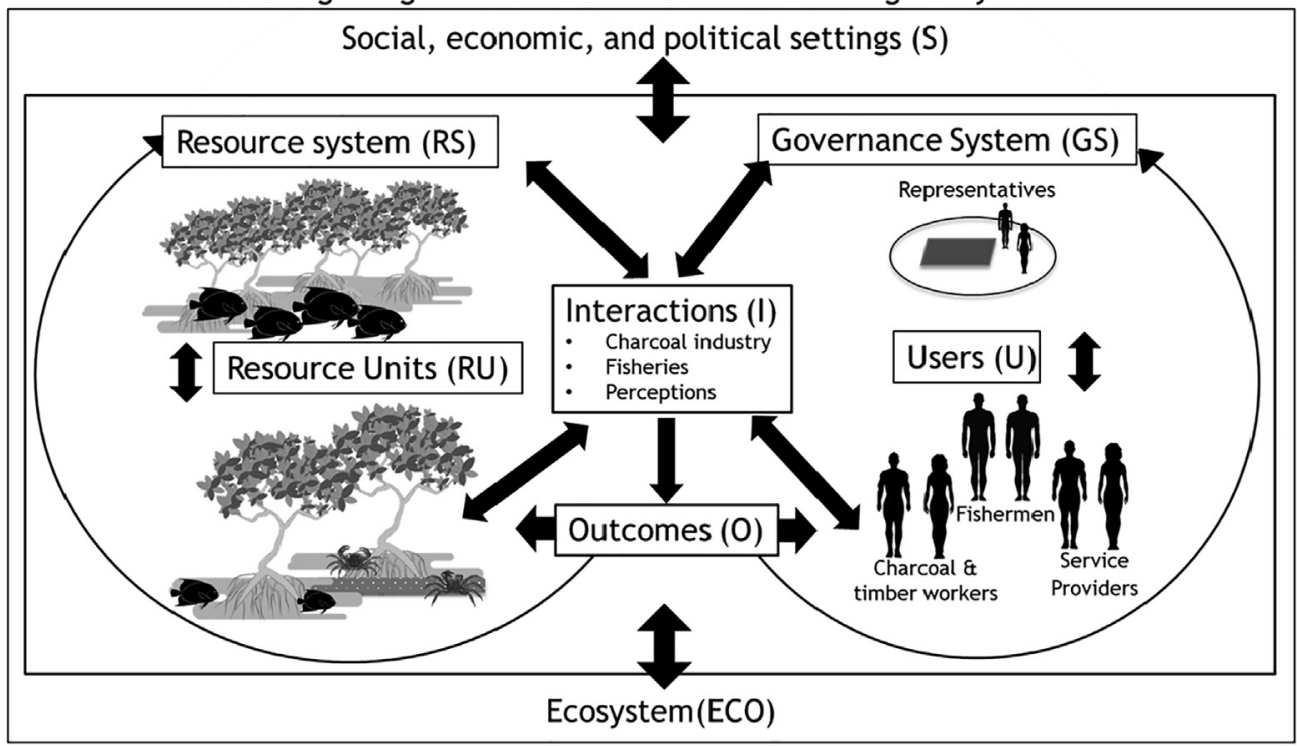

Fig. 1. Ostrom's framework applied to Matang Mangrove Forest Reserve-Social Ecological System showing the four subsystems: (i) Resource system-mangrove forest ecosystem, (ii) Resource Units- flora and fauna biodiversity, (iii) Governance System- Perak state representatives and (iv) Users- local stakeholders those units are interacting (charcoal and timber industry, fisheries ) and producing outputs that are related to the ecosystem and the social, economic and political settings.
Globally, mangroves are key ecosystems that provide a wide array of goods and services that contribute to many human communities (Ewel et al., 1998; Santos et al., 2017) Mangroves have traditionally provided raw materials (e.g. timber, fuel, and food) (Barbier et al., 2011; Nfotabong- Atheull et al., 2009); they serve as nurseries for different fishes, crustaceans and mollusc species, thereby sustaining biodiversity and proving their interdependence to the nearby (marine) ecosystems such as seagrass beds and coral reefs (Mumby et al., 2004). These interrelations bring benefit to the local populations (e.g. in terms of income sources) (Nagelkerken et al., 2008; Satyanarayana et al., 2013). Apart from these direct benefits, mangroves also provide several indirect benefits such as coastal protection and wave attenuation, in the case of physical impacts like tsunamis (Adeel and Pomeroy, 2002; Dahdouh-Guebas et al., 2005; Feagin et al., 2010). On a larger scale, being the interface between terrestrial and marine ecosystems, they also play a crucial role in nutrient cycling regulation and carbon storage (Donato et al., 2011).

\subsection{Mangrove forest management}

Despite all the benefits they provide to humans, mangrove forests are threatened by a range of anthropogenic activities. Loss of mangrove cover increased significantly since 1970 (Giri et al., 2011; Richards and Friess, 2016), and the remaining forest patches are under pressure from clear-cutting, land-use change, hydrological alterations, chemical pollution and climate change (Lee et al., 2014; Mukherjee et al., 2014b). Southeast Asia, the region of largest and most biodiverse mangrove ecosystems on Earth (Appeltans et al., 2012; Giri et al., 2011; Spalding, 2010), is also facing a highest rate of deforestation since 2000 (Hamilton and Casey, 2016; Richards and Friess, 2016). This clearly signifies the importance of policy interventions to ensure a sustainable mangrove management not only for Southeast Asia but all over the world (Richards and Friess, 2016).

This is particularly relevant to Malaysia that holding sixth largest remaining mangrove forest in the world next to Indonesia, Brazil, Australia, Mexico and Nigeria, representing nearly $4.7 \%$ of global mangrove cover (Blasco et al., 2001; Hamilton and Casey, 2016; Spalding, 2010). In Peninsular Malaysia, mangroves are mostly distributed along the west coast due to sheltered environment than to the east coast that is entirely exposed to the South China Sea (Satyanarayana et al., 2018). In 1902, the largest mangrove area covering 40200 ha on the west coast was declared as Matang Mangrove Forest Reserve (Ellison, 2008).

Promoting sustainable mangrove management is by no means an easy task, as mangrove management, just like other environmental challenges, involves complex dynamic interactions between natural and social systems (Berkes et al., 2000; Folke et al., 2005; Ghazoul, 2007). In this context, social-ecological assessments serve as a major tool for coastal management, as they allow to translate social-ecological information into policy decisions. Such decision-making processes ideally link mangrove-dependent communities and mangrove managers (Santos et al., 2017; Young et al., 2018).

Historically, the relation between people and nature has been changing, resulting in different framings of conservation and natural resources management. Mangrove ecosystems and their resources used by humans can be approached as social-ecological systems (SES). The SES framing proposes to divide a system into four compartments (Resource system, Governance System, Resource units and Users) interacting and producing outcomes (Ostrom, 2009). The successful management and study of a SES demands the study of the interaction between ecological and social science (Glaser et al., 2010). Encompassing trade-offs and synergies between ecological, social and economic objectives are key for a sustainable management of SESs (Rose, 2014). Subsequently, the decision-making process regarding natural resource management and conservation should be driven by the interaction between verifiable, scientific data and value-based opinions from a wide range of stakeholders (Mace, 2014).

\subsection{Forest management in Matang mangrove forest reserve}

Matang Mangrove Forest Reserve (hereafter referred to as 'MMFR') is under the jurisdiction of Perak state and monitored by the Forestry Department (Amir, 2012; Talbot and Wilkinson, 2001).

In fact, MMFR is the longest actively and formally managed mangrove forest in the world (Goessens et al., 2014; Ariffin et al., 2013). More than one hundred years ago, i.e., in 1904, the first management plan for sustainable production of timber and fuelwood was drafted for MMFR (Jusoff and Taha, 2008a). This management regime was translated into operational guidelines through a 'Working Plan'. This working plan focused on the forest compartments allocated for clear-felling (30year-old forest patches) for charcoal production and intermediate thinning (15 and 20-year-old forest patches) to obtain poles (Ariffin and 
Nik Mohd Shah, 2013). The working plan is evaluated and modified once in ten years by the Perak Forestry Department (Clough, 1993; Othman et al., 2004).

The provision of services by the MMFR-SES shown in Fig. 1 depends on the status and functioning of the ecosystem (Duke et al., 2007), the diversity of ecosystem services are also dependant of the type of mangrove forest, MMFR counts with different types of forest i.e. fringe, riverine, and basin forest (Ewel et al., 1998). Despite being the longest managed mangrove forest in the world, still there are several uncertainties- especially in relation to the socio-economic and ecological concerns including future management of the reserve. The MMRF has mainly been managed for silvicultural purposes, although there are many other services offered by the mangroves that may or may not be compatible with the main goals of the current management regime (Hugé et al., 2016).

\subsection{Preceding social and ecological studies in MMFR}

Since the reserve was created, only a few ecological studies have been carried out e.g. regarding mud crab population dynamics (Kosuge, 2001); distribution and feeding habits of fish species (Kiso and Mahyam, 2003) and mangrove rejuvenation (Goessens et al., 2014).

Socio-economic components of the MMFR system have been studied by Ahmad, (2009), who conducted an assessment of the recreation values of MMFR, and Hugé et al. (2016) who identified the discourses on the ongoing MMFR management among the different stakeholders involved.

Coupling of ecological and social knowledge is essential to understand and manage the MMFR in a sustainable way (Mace, 2014; Ostrom, 2009). Before coming up with an effective collaboration for mangrove management, a process of understanding the roles and relationships among the local stakeholders is required. With the present study, we aim at contributing to a better understanding of the MMFRSES through studying stakeholders and their perceptions.

This is a follow-up study to Hugé et al., (2016) who mapped the discourses in MMFR management based on a broad group of stakeholders. The term discourse is used here to refer to a shared, structured way of interpreting, thinkig and representing a specific topic (Barry and Proops, 1991; Hugé et al., 2016). Discourses were identified using Q methodology (Zabala et al., 2018), a semi-quantitative tool with multivariate data reduction techniques that synthesizes individual stakeholders' rankings of statements into a typology of perspectives that represents the main clusters of stakeholders' perspectives (Mukherjee et al., 2018).

Hugé et al., (2016) identified three main discourses shown in Fig. 2 and concluded that they have some points in common (shared statements), which provide opportunities for possible modifications in the (ongoing) mangrove management regime based on consensual opinions. So $\mathrm{Q}$ identifies and characterizes the diversity of discourses, but does not tell us which discourse is more/less popular among the concerned stakeholders (Addams and Proops, 2000; Danielson, 2009). In this study, we aim to address this. We map the support base of local stakeholders towards the different discourses, and their particularities depending on their working category. The results can guide decisionmakers towards a more sustainable, collaborative management of the reserve.

\section{Methodology}

\subsection{Study area}

When the reserve was created, Perak state was part of a British protectorate, meaning that the British controlled their foreign policy. In 1885, the first railway line of Malaysia was opened between Port Weld (now Kuala Sepetang) and Taiping, mainly because of the need of the British to transport tin and rubber to the Strait of Malacca. The (mangrove) charcoal produced in the reserve was also used as fuel for the train, although the train is no longer running, charcoal production continues for export. (Andaya and Andaya, 2016; Jabar et al., 2014; Quispe Zuniga, 2014).

MMFR is located in the administrative districts of Krian and Larut Matang, bordering the Selinsing River on the west coast of Peninsular Malaysia as shown in Fig. 3 a-c (Ariffin and Nik Mohd Shah, 2013; Ibharim et al., 2015). The Matang mangroves can be divided into mainland forest (30\%) and island forest $(70 \%)$ under three forest ranges: Kuala Sepetang, Kuala Trong and Sungai Kerang. The fishing villages located in the vicinity are Kuala Gula, Kuala Sangga, Bagan Pasir Hitam, and Bagan Panchor. Except Kuala Gula, all other fishing villages exist within the forest reserve (Ariffin and Nik Mohd Shah, 2013). The present study was conducted at Kuala Sepetang as shown in Fig. $3 \mathrm{~d}$ - the largest administrative range of the MMFR.

In 2014, Kuala Sepetang has an estimated population of 5670 people - 2901 (51\%) male and 2769 (49\%) female, with an average no. of people per households as 6.1 (Perak Government, 2014). The population of this district has a multiracial configuration: Malay (59.97\%), Chinese (26.02\%), Indian (10.79\%) and No-Citizenship (2.14\%) (Perak Government, 2014). A demographic study reported that from a total of 1276 inhabitants of Kuala Sepetang, 54\% were in a range of $16-54$ years old, $38 \%$ were $0-15$ years old and $7.36 \%$ were above 54 years old (Nuruddin and Fong, 1994). Within the gender ratio of $52 \%$ female and $48 \%$ male, only $14 \%$ of the females and $58 \%$ of the male are actively working (Nuruddin and Fong, 1994). These statistics served as a baseline proportions of active working population expected to find in our study. Nowadays, the MMFR shown in Fig. 3c provides benefits to the local residents, whose main activities are related to charcoal and timber harvesting; fish and shrimp catching, cockle rearing, and tourism (Ahmad, 2009).

\subsection{Data gathering: Face to face interviews}

A stakeholder analysis approach, as proposed by Reed et al. (2009) was chosen to evaluate the local stakeholders' perception towards the ongoing management of MMFR. Hugé et al. (2016) have applied Q methodology to complete Reed et al.'s Step 1 (identifying all types of stakeholders) and Step 2 (map stakeholder discourses).

To assess discourse popularity, a numerical survey method is beneficial to (i) extend and generalize the results to a larger population, and (ii) identify linkages between discourse preferences and stakeholder variables such as employment category, age, gender, etc. (Danielson, 2009).

An assessment of the popularity (i.e. the rates of approval) of the three discourses identified by Hugé et al., (2016) was carried out in this study. These findings can be significant to the management of MMFR since Kuala Sepetang is the main settlement in MMFR. Hence this study aims at contributing to (I) a better understanding of the possibility to generalize perspectives among the population, (II) correlating working categories with perceptions and, (III) identifying signals about why a stakeholder holds a particular perspective as shown in Fig. 4.

\subsubsection{Development of the questionnaire}

The discourses found by Hugé et al., (2016) were based on the ranking of 48 initial statements. The Scale Creation Technique, was used to measure the adherence to a discourse by the average of the score of each statement, resulting in the identification of the popularity of every discourse (Danielson, 2009). This method is widespread in education and social sciences, and has been considered before in environmental management (e.g. Rastogi et al., 2013).

The first step involved was the selection of highly ranked $(+3,+2$, $-3,-2)$ exclusive statements, from each $Q$ discourse. These statements complement each other, addressing the different pillars (social, ecological and economic) of each discourse. In total, 19 statements were obtained and presented in Table 1. 


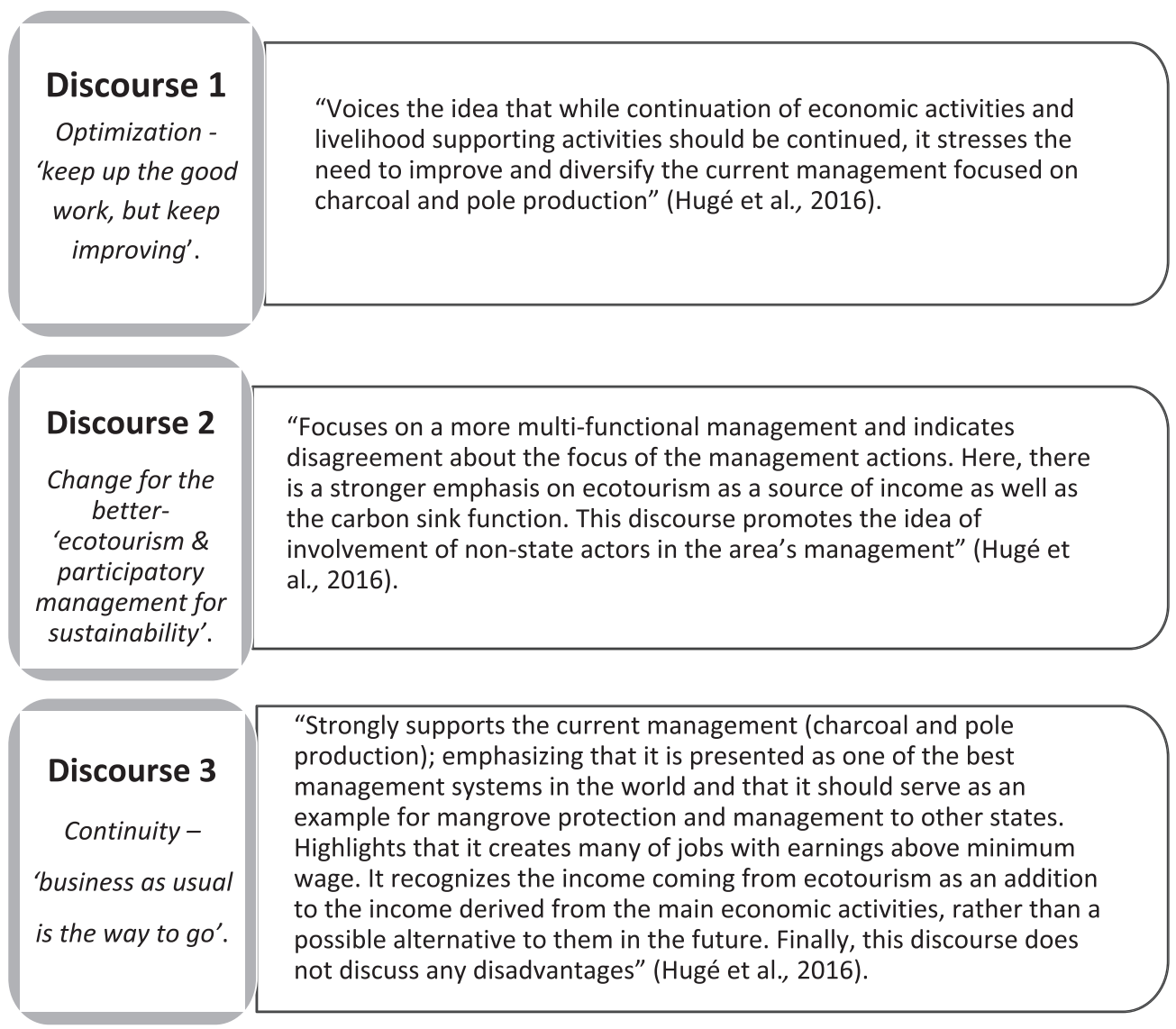

Fig. 2. Local discourses narrative identified regarding the management of MMFR obtained through Q methodology (Hugé et al., 2016).

The new selection was composed of five statements corresponding to Discourse 1: Optimization- 'keep up the good work, but keep improving'; seven corresponding to Discourse 2: Change for the better'ecotourism \& participatory management for sustainability'; and seven others corresponding to Discourse 3: Continuity - 'business as usual is the way to go'.

Subsequently, these statements were presented to the respondents, as items to be scored on a Likert scale (Appendix 1.1). To keep the balance and avoid bias, some statements were reformulated and presented as implicitly negative, that convey a negative meaning but avoiding double negatives that could lead to confusion of the respondent (Converse and Presser, 1986). To avoid any misunderstandings and to increase survey participation (Loyau and Schmeller, 2017), the questionnaire was originally drafted in English and then translated into Malay and Chinese languages (Appendix 1.2).

The participants ranked each statement using a 7-point Likert scale $(-3,-2,-1,0,1,2,3)$ where -3 means complete disagreement and +3 complete agreement.

\subsubsection{Conducting the interviews}

First, the questionnaire was presented to the Perak State Forestry Department, which authorized access to the charcoal factory workers. They also facilitated contacts with other stakeholders of Kuala Sepetang such as fishermen. The data collection was done in July-August 2016. We used stratified random sampling (Marshall, 1996) in which the target population was divided into subgroups or categories since we wanted to identify the effect of their working category on their perception towards the MMFR management. In this study, three main categories of professional activities conducted by local stakeholders in Kuala Sepetang were identified (Quispe Zuniga, 2014) and shown in Fig. 5. Charcoal and timber workers, as well as fishermen, extract raw materials from the forest, while service providers have an indirect interaction with the forest. Service providers include restaurant owners and shopkeepers who buy the products from the fishermen and from the charcoal industry and who increases the value of the forest products. The ecotourism employees are dependent on the recreational value of the MMFR. Any changes in the mangrove ecosystem would affect all working categories, their profit and forest product/resources finally. The number of people involved in each category was not equally divided, therefore three different sample sizes were selected(Kitchenham and Pfleeger, 2002). Participants of this study were identified at their work place (e.g. port, charcoal factories, restaurants, etc.), at different time intervals to reach as many participants as possible.

A face-to-face interview methodology was followed, and the participants also had a hard copy of the questionnaire in hand. The questionnaire was pilot-tested with students of the UMT (Universiti Malaysia Terengganu) and other community members (of different ages, gender, profession and educational level). These tests were useful to ensure the clarity of the questionnaire. After subsequent modifications, all participants answered the questionnaire satisfactorily (Appendix 1.2). They could decide if they wanted to answer the questions themselves, and ask questions in case they did not understand the question, or to be interviewed. The majority of the participants preferred to be interviewed, therefore, we collaborated with a MalayEnglish and a Chinese-English translator to perform oral translation.

\subsection{Sampling method}

\subsubsection{Sample size}

2.3.1.1. Variance and error estimation. The scale-variable variance was calculated considering the inclusive range of the scale and then divided by the number of standard deviations that would include all possible values of the range. Of the responses, $98 \%$ had been captured as indicated in Eq. (1) (Cochran, 1977), 

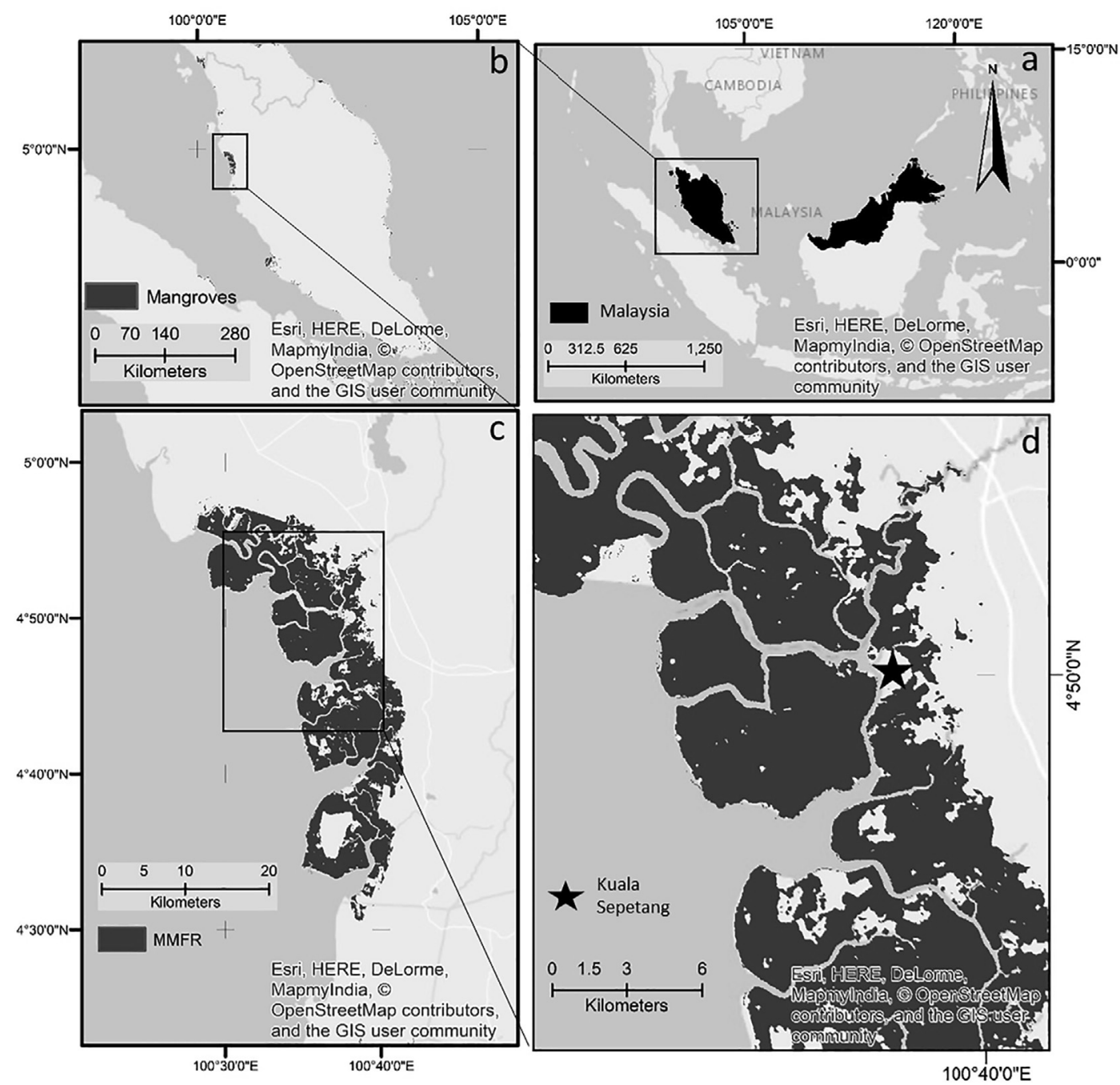

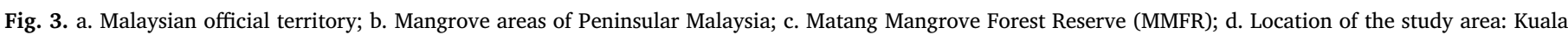
Sepetang.

$s=(x) /(y)$

where, $x$ is the number of points on the scale and $y$ the number of standard deviations.

The $a$ priori alpha level for this study was 0.05 , with a seven-point scale, with an acceptable error of $3 \%$, and an estimated standard deviation of the scale of 1.167 . The number of participants was decided based on Cochran's sample size formula for continuous data (Eq. (2)),

$n_{0}=\left(t^{2} S^{2}\right) / d^{2}$

where, $\mathrm{t}$ is the confidence level (alpha value of 0.025 in each tail $=1.96), s$ the standard deviation in the population, and $\mathrm{d}$ is the confidence interval of marginal error for a mean estimated (0.21). Considering an active working population of $\sim 500$ people (Perak government, 2014) correction was applied (Eq. (3)),

$n=n_{0} /\left(1+n_{0} / p o p\right)$

where, $\mathrm{n}_{0}$ is the sample size when the population is infinite and pop is the population size number. This resulted in a minimum of 80 people (n) with a confidence level of 90 percent $(\alpha=0.1)$.

2.3.1.2. Demographic variables. In order to explain the perspectives of the participants, demographic variables were collected: age, period of living in Kuala Sepetang district, education, civil status and gender. These demographic variables have the ability to show how a perspective is related to aspects the initially presented Q statements (Danielson, 2009).

\subsection{Data analysis}

2.4.1. Statements popularity: Identification of consensus statements, and differences among working sectors.

The ranking of the statements is based on approval percentage. When the approval is $>50 \%$ then it is considered to be a statement in consensus within all the working categories. This means that the majority of the participants of the three categories agreed with the statement. The frequencies of every score of every statement were calculated. Subsequently, a Shapiro-Wilk test was applied, showing a nonnormal distribution. Then all statements were tested pairwise between working categories (fishermen - charcoal and timber workers, fishermen - service providers, service providers - charcoal and timber workers).

In order to compare three independent samples with different sample size and non-normal distribution of residuals, a non-parametric Kruskal-Wallis test was applied (Eq. (4)) (Kruskal and Wallis, 1952).

$H=(N-1) \frac{\sum_{i=1}^{g} n_{i}\left(\overline{r_{i}}-\bar{r}\right)}{\sum_{i=1}^{g} \sum_{j=1}^{n_{i}}\left(r_{i j}-\bar{r}\right)}$

where, ni is the number of observations in a group $i, r_{i j}$ is the rank of 


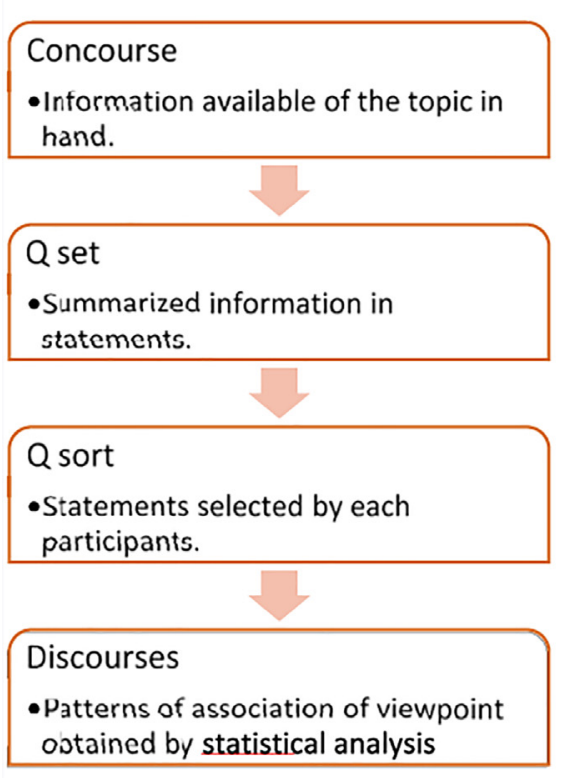

Discourses
-Identified point of views.

Exclusive statements

-Shortlist of representative statements of each Discourse.

\section{Questionnaire design \\ - Conversion of exclusive statements in questions.}

Interviews
- Performance of face to face interviews to
stakeholders of target population.

\section{Data analysis}

\section{Statement analysis}

-Statements' approval rate.

\section{Discourse analysis}

- Discourses' popularity identification.

\section{Q discourses validation \\ - Survey and Q methodology comparison.}

\section{Extrapolation}

- Generalize sample results to a larger population.
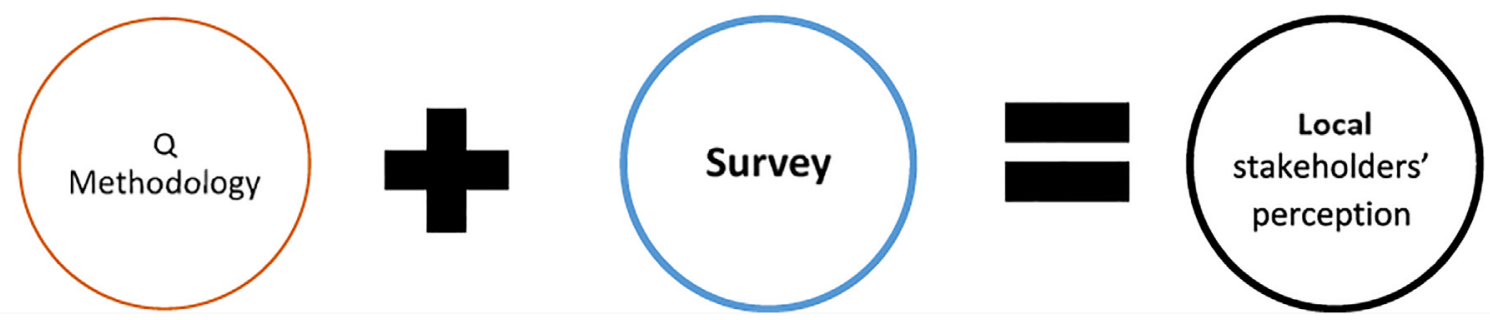

Fig. 4. A complete view of the stakeholder analysis, including a brief explanation of Q methodology (Hugé et al., 2016), coupled with a survey methodology (blue) and the data analysis (black) done in the present study. (For interpretation of the references to color in this figure legend, the reader is referred to the web version of this article.)

the total observations; $\mathrm{N}$ is the total number of observations across all groups, $\bar{r}$ is the average rank of all observations in a group i and $\bar{r}$ is the average of all the $\mathrm{r}_{\mathrm{ij}}$ (Kruskal and Wallis, 1952). The results of this test determined which statements are popular among the total population and which ones are supported only by a subgroup characterized by a certain employment category.

Table 1

Selected high ranking exclusive statements with their corresponding rank from the original Q methodology study of Hugé et al., (2016), that define the viewpoint of each discourse.

\begin{tabular}{|c|c|c|c|}
\hline Discourse & Statement number & Statement & Rank \\
\hline \multirow[t]{5}{*}{1} & 18 & Conservation of biodiversity (the diversity in plant \& animal life) is important in Matang mangroves & +3 \\
\hline & 23 & The tree logging and cutting cycle in Matang is closely related to the natural cycle. & +2 \\
\hline & 24 & The management of Matang mangroves is sustainable from an economic point of view (profit can be maintained year after year). & +2 \\
\hline & 41 & There are no conflicts between people regarding access to land and natural resources (timber, fish, etc.) & -2 \\
\hline & 17 & The primary objective of management of Matang mangroves is the production of charcoal and poles. & -2 \\
\hline \multirow[t]{7}{*}{2} & 3 & $\begin{array}{l}\text { Mangroves are most important because they provide a carbon } / \mathrm{CO}_{2} \text { sink (they store carbon and hence they are important in mitigating } \\
\text { climate change). }\end{array}$ & +3 \\
\hline & 5 & Ecotourism is an important source of income in Matang. & +2 \\
\hline & 25 & $\begin{array}{l}\text { The management of Matang mangroves is sustainable from a social and ecological point of view (quality of environment and quality of } \\
\text { people's life can be maintained year after year). }\end{array}$ & +2 \\
\hline & 40 & Everyone involved in the management of Matang forest shares a common goal. & +2 \\
\hline & 43 & Local communities and fishermen, as well as NGOs, should be involved in the management of Matang mangroves. & +2 \\
\hline & 37 & Shrimp culture should be allowed in Matang mangrove forest. & -3 \\
\hline & 9 & The water in Matang mangroves is polluted due to industrial activities, palm oil mills and rubber factories inland. & -2 \\
\hline \multirow[t]{7}{*}{3} & 39 & Mangrove protection is an important task for all states in Malaysia (not only Perak). & +3 \\
\hline & 42 & The Forestry, the Fisheries Department and the Wildlife Department collaborate efficiently to manage Matang mangrove forest. & +2 \\
\hline & 48 & Matang mangroves forest creates a lot of jobs. & +2 \\
\hline & 14 & The bird population in Matang is declining (especially migrating shorebirds). & -3 \\
\hline & 8 & Among the charcoal and pole workers, only tree cutters earn more than minimum wage & -2 \\
\hline & 12 & Fish catch is declining over the years in Matang region. & -2 \\
\hline & 15 & The demand for charcoal and poles is increasing and causes strong pressure on the mangroves forest. & -2 \\
\hline
\end{tabular}




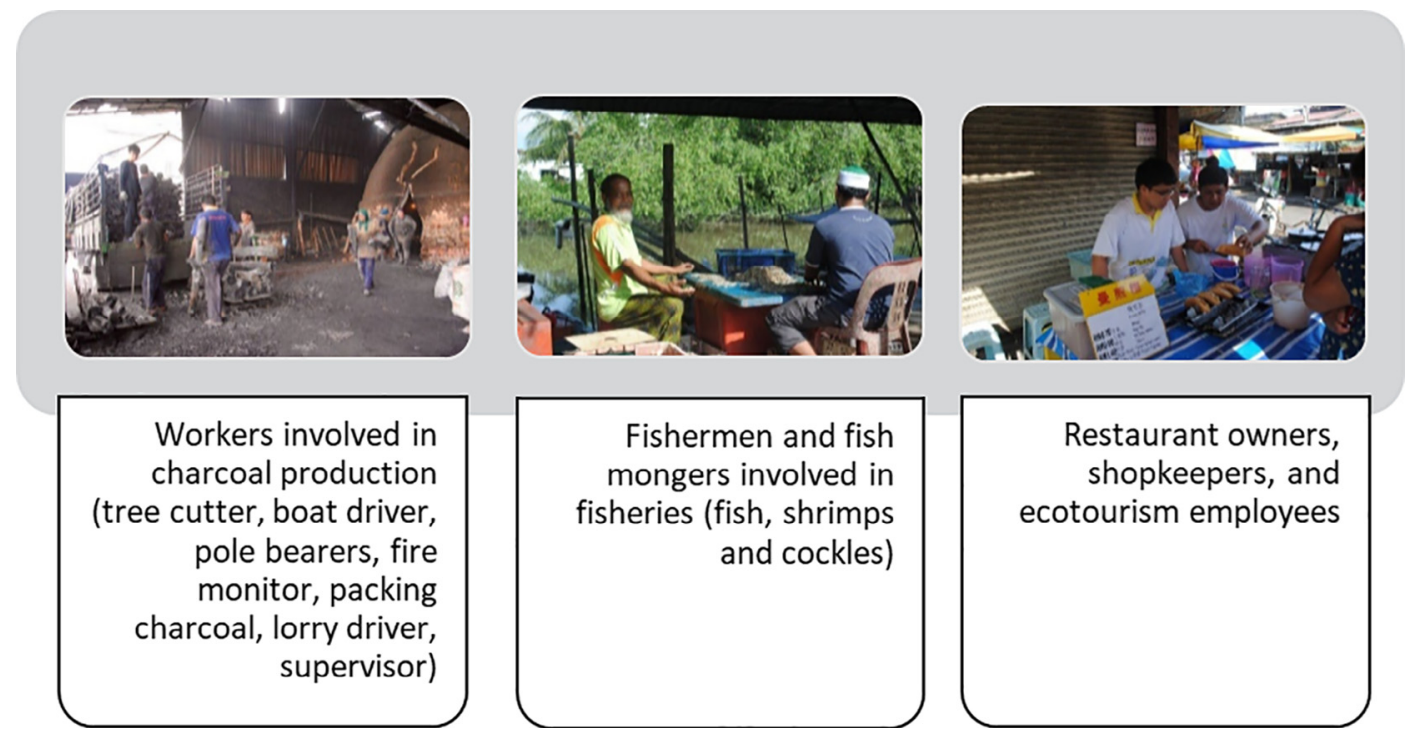

Fig. 5. Professional activities grouped into three main working categories: (I) charcoal and timber workers, (II) fishermen and (III) service providers.

\subsubsection{Discourse popularity: Identification of the distribution of profiles among working categories}

The agreement of each discourse is determined by the sum of the statements to which each participant agreed or disagreed. If the participants ranked the statement as expected it was considered a total agreement with that statement. In case the participant ranked as expected all statements within the discourse, then the total agreement $(100 \%)$ to that discourse is reached. To analyse the results, the scale -3 to 3 was transformed to 0 to 7 . When the participants ranked the statement negatively $(-3,-2,-1)$ in a statement that needed to be negative to be in agreement with certain discourse, the scale was inverted, considering the negative as the maximum score (7). Moreover, the scores were weighted by the number of statements of each discourse, to compensate the bias if any, and to obtain comparable final ranks per discourse (Davis and Rabinowitz, 2007).

At discourse level, the distribution of rankings was non-normal, therefore a non-parametric Kruskal-Wallis test was applied. Comparison of the distribution of agreement across the three working categories per discourse is presented as density plots. A density plot can combine the ability of the boxplot to display trends invariance, and the kernel density can present the precise shape of the population distribution (Cohen and Cohen, 2006), all the statistical analysis were performed in R studio.

\section{Results}

Among the 114 respondents who participated in the present study, sixty-one participants work in charcoal and timber production, twenty are fishermen and thirty-three are service providers as shown in Table 2. The (average) age of the participants was 39 years, similar to their (average) period of living in Kuala Sepetang district (34.75 years). Fifty-two percent of the participants completed secondary education. Majority of the participants were men $(68.42 \%)$. From the total sample (women and men) $66.66 \%$ of the participants were married.

\subsection{Approval of statements within the local stakeholders}

The statements that were supported by $>50 \%$ of the participants are presented in Table 3. The complete ranking results are presented in Appendix 1.3. The statement that obtained the highest approval rate (88.60\%) among the participants with the expected rank corresponded to S39: "Mangrove protection is an important task for all states in Malaysia (not only Perak)" one of the core statements of Discourse 3. Subsequently, S17: "The primary objective of management of Matang mangroves should be the production of charcoal and poles" obtained the secondhighest frequency of the expected rank (-3), this strong disagreement was the expected result for people that agree with Discourse 1 . Nine of the statements in the questionnaire were ranked high $(+3)$.

Table 4 shows the six statements that were significantly different ( $p$ $=$ less than 0.05 ) between the working groups. The fishermen's perceptions of logging and cutting cycle (S23-D1), carbon sink (S3-D2) and bird population decline (S14-D3) were different from the perception of charcoal workers and service providers.

The charcoal workers' perception of 'conflict between employment activities regarding land use (statement 41-D1)', 'charcoal production as the main economic activity' (statement 17-D1), and 'money earned differences among the charcoal workers was only acknowledged by charcoal workers' (statement 8 -D3).

\subsection{Discourse approval among local stakeholders}

Perception among sampled groups $(n=114)$ regarding Discourse 3 was significantly different $\left(\chi^{2}=6.60, P=0.036\right)$, while the perception towards Discourse $1\left(\chi^{2}=4.1876, P=0.123\right)$ and Discourse 2 $\left(\chi^{2}=0.569, P=0.752\right)$ was shared among working categories (Fig. 6). Consequently, for Discourse 3 , the perception between charcoal workers - fishermen $(n=81)$ was found to be significantly different $(t=-2.77, P=0.0047)$.

Stakeholders appeared to share different discourses, the distribution

Table 2

Demographic variables summary of the 114 participants of Kuala Sepetang community of MMFR, Perak Malaysia.

\begin{tabular}{|c|c|c|c|c|c|c|c|c|c|c|c|c|c|}
\hline \multicolumn{3}{|c|}{ Age (years) } & \multicolumn{3}{|c|}{ Time living in Kuala Sepetang district (years) } & \multicolumn{4}{|c|}{ Education } & \multicolumn{2}{|c|}{ Civil Status } & \multicolumn{2}{|c|}{ Gender } \\
\hline Range & $\mathrm{Avg}^{1}$ & S.D. & Range & $\operatorname{Avg}^{1}$ & S.D. & Primary & Secondary & High school & Diploma & $M^{*}$ & $\mathrm{~S}^{*}$ & M & $\mathrm{F}$ \\
\hline $16-74$ & 39.07 & 12.1 & $0.5-74$ & 34.75 & 15.78 & 42 & 60 & 2 & 5 & 79 & 35 & 78 & 36 \\
\hline
\end{tabular}

${ }^{1}$ No significant difference between average and median was identified, therefore only average is shown.

*M = Married; $\mathrm{S}=$ Single. 


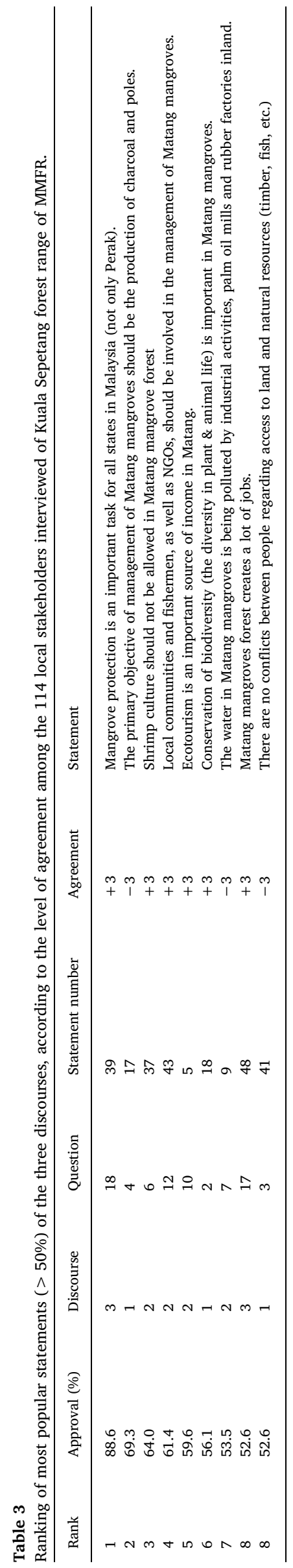

of their support towards each discourse is shown in Fig. 7 a-c.

As for the perception of all participants $(n=114)$ (Fig. 8), the agreement distribution per discourse was higher towards Discourse 2 $(\mu=0.72 \pm 0.12)$. However, the ranking of agreement towards the three discourses was always higher than 0.5 . Discourse 1 obtained the lowest rank $(\mu=0.51 \pm 1.25)$.

Discourse rankings are based on the number of statements approved by the majority of the participants. The statements have been grouped per discourse (Fig. 9).

Each discourse had statements in consensus within working categories (approval percentage higher than 50\%) and some other statements supported or rejected by only one of the working categories.

Nine out of nineteen statements were supported by a majority of participants in the present study, which indicates relatively low polarization. Nevertheless, none of the discourses was agreed by the totality of the working categories. Discourse 2 - Change for better 'ecotourism \& participatory management for sustainability', turned out to be most popular among the stakeholders.

Discourse 1 - Optimization 'keep up the good work, but keep improving' obtained the least total support compared to the other two discourses. Service providers were the group which showed most support $(56 \%)$ towards this discourse. Fifty-six percent of the participants agreed $(+3)$ with the statement 'conservation of biodiversity as an important task for Matang mangroves' (S18). This statement is not part of Discourse 3, suggesting that the relevance of mangrove forests beyond charcoal production is generally acknowledged by local stakeholders, yet not part of "the official discourse" (D3). The only statement rejected by all working categories was S24, stating that the current management of Matang mangroves is sustainable from an economic point of view. This result voices local stakeholders' discrepancy of the economic profit.

The "official discourse", Discourse 3 - Continuity 'business as usual is the way to go' was ranked as second. The most popular statement was (S39- D3) 'mangrove forest protection should be an important task in Malaysia' (88\% of the participants) agreed $(+3)$, highlighting that conservationist and protectionist vision of the forest is well spread among the local stakeholders. Additionally, the only other statement of Discourse 3 supported by $>50 \%$ of the participants was S48- 'Matang mangroves forest creates a lot of jobs'. Fishermen were most supportive of this discourse.

Discourse 2- Change for the better 'ecotourism \& participatory management for sustainability', proved to be the most popular discourse $(72 \%$ support) among the local stakeholders. Regardless of the participants' working category as shown in Fig. 8, and it always obtained the highest mean within categories as shown in Fig. 7 a-c. Four of seven statements were agreed by $>50 \%$ of the total participants. The most popular statement of Discourse 2, was S37, stating that 'shrimp aquaculture should not be allowed in MMFR', which was agreed $(+3)$ by $64 \%$ of the participants. Non-significant differences within working categories were detected towards this statement, assuming a shared vision across working categories.

A support of 61\%, for D2-S43 - 'Local communities and fishermen, as well as NGOs should be involved in the management of MMFR', hints at a willingness of being part of the decision-making process instead of relying on centralized governmental agencies (in particular the Perak Forestry Department). Respondents stated that there is ineffective cooperation between the decision-makers and institutions involved in the current management (15\% and $22 \%$ of the participants agreed with S40: "Everyone involved in the management of Matang forest shares a common goal" and S42: "The Forestry, the Fisheries Department and the Wildlife Department collaborate efficiently to manage Matang mangrove forest" respectively).

Subsequently, 60\% agreed with D2-S5 - 'Ecotourism is an important source of income in Matang'. Local stakeholders (fishermen, charcoal ant timber workers, acknowledge that ecotourism could bring them higher economic benefits). D2-S9 - 'Water in Matang mangroves is polluted due to industrial activities, palm oil mills and rubber factories inland' 
Table 4

Kruskal Wallis test: Identification of a working category agreement towards a statement that differs significantly with the other two working categories' perceptions.

\begin{tabular}{|c|c|c|c|}
\hline Discourse & Statement number & Statement & Working categories \\
\hline 1 & 23 & The tree logging and cutting cycle in Matang is closely related to the natural cycle. & fishermen \\
\hline 1 & 41 & There are no conflicts between people regarding access to land and natural resources (timber, fish, etc.) & charcoal- \& timber workers \\
\hline 1 & 17 & The primary objective of management of Matang mangroves should be the production of charcoal and poles. & charcoal- \& timber workers \\
\hline 2 & 3 & $\begin{array}{l}\text { Mangroves are most important because they provide a carbon } / \mathrm{CO}_{2} \text { sink (they store carbon and hence they are } \\
\text { important in mitigating climate change). }\end{array}$ & fishermen \\
\hline 3 & 14 & The bird population in Matang is declining (especially migrating shorebirds). & fishermen \\
\hline 3 & 8 & Among the charcoal and pole workers, only tree cutters earn more than minimum wage & charcoal- \& timber workers \\
\hline
\end{tabular}

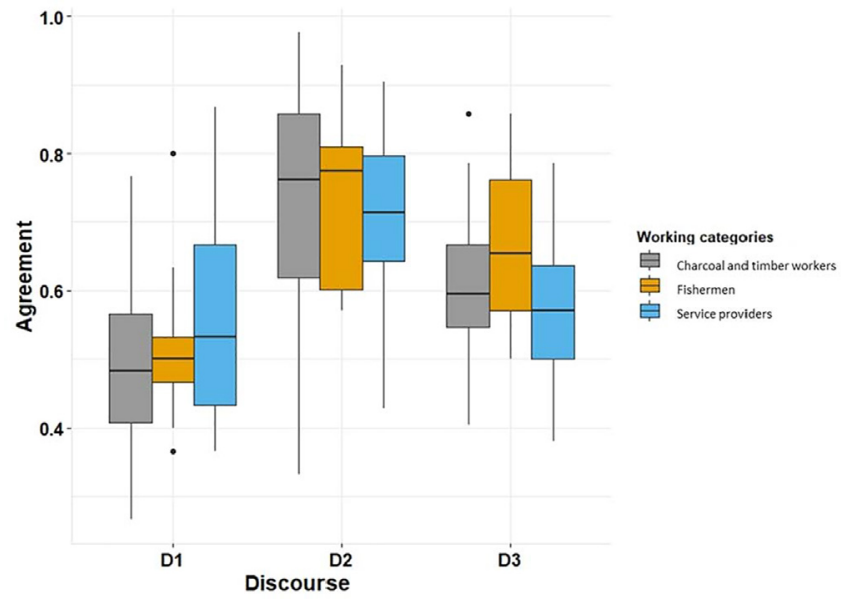

Fig. 6. Boxplots illustrating the agreement among working categories regarding each of the discourses (indicated by D1-Optimization 'keep up the good work, but keep improving', D2- Change for better 'ecotourism \& participatory management for sustainability' and D3- Continuity 'business as usual is the way to go'). Bold lines represent medians, and the whiskers extend until the lowest/highest value within $1.5 \mathrm{IQR}$ of the lower/upper quartile.

was disagreed (-3) upon by $54 \%$ of the participants. The only statement from D2 which obtained significantly different levels of support among the working categories was S3-D2 'Mangroves are most important because they provide a carbon/CO2 sink (they store carbon and hence they are important in mitigating climate change'. Since this statement was ranked low (22\%) among all participants, this result is not conclusive about a specific profile.

\section{Discussion}

MMFR is not a pristine reserve with mere biodiversity conservation objectives, instead it has been managed to produce charcoal and timber for over a century. During this period, many other ecosystem services have been provided aside from the main goal of the official forest management. The possible overestimation of the current forest management success is grounded in the studies focusing on the sustainability of the charcoal production (Goessens et al., 2014; Khoon and Eong, 1995), which led to a comparative neglect of other important ecosystem services (as mentioned by Ewel et al., 1998). Hence there is still room for an improved management, e.g. to balance nature protection for human's sake (instrumental values) with nature's intrinsic values and to ensure that well-being of the local population is duly considered.

The Q methodology study of Hugé et al. (2016), helped to frame the main discourses and identified possible conflictual issues. The results of this study suggest that local stakeholders agreed mostly with Discourse 2. Moreover, each working category has their own perceptions and expectations regarding their own situation and role in the MMFR-SES.

Local stakeholders' perception is a key element of a robust decisionmaking process because these stakeholders directly interact with the reserve's natural resources, and they are the first-hand receptor of its benefits as well as challenges (Hugé et al., 2016; Rastogi et al., 2013). Their perception and participation in the management and inclusion of the policies should be encouraged.

The results of the present study indicated that, while the continuous development of charcoal production is supported, opportunities to diversify the current management objectives are also supported by local stakeholders. This study unveils local stakeholders' support to each discourse to different degree, i.e. service providers support D1, charcoal and timber workers D2 and fishermen D3. It highlights the current management system's aspects that local stakeholders perceive as either positive or subject to improvement.

Local stakeholders are not against the current management discourse (D3) since they recognise that the majority of the jobs are related to the existence of the mangrove forest (as seen in Quispe Zuniga, 2014). Additionally, charcoal workers, represent, the only working category that supports S17-D3, 'the primary objective of the management of Matang mangroves should be the production of charcoal and poles', a key pillar of this discourse (D3). Acknowledging that the management of the reserve as charcoal producer has been running for more than a century, it seems logical that local stakeholders take this statement for granted.

Besides this evidence, some concerns were expressed about wellbeing trade-offs. The lowest agreement towards the official discourse (D3) was found in the statements on current working conditions. The average annual stakeholder income changes depending on their working category. Stakeholders that are labourers in only fishery and charcoal activities earn less than 12,000 $\mathrm{RM} \mathrm{y}^{-1}$, stakeholders involved in marketing activities (service providers), fishing asset-owners earn a total annual income above $35,000 \mathrm{RM} \mathrm{y}^{-1}$, but depending on the gear operated and fish product their profit will increase or decline. Every fishing stakeholder is above the poverty line, which is not always the case for the charcoal workers (Goessens et al, 2014). These facts are aligned with the support (56\%) to statement S5-D2 'Ecotourism as important source of income in Matang' and the agreement of charcoal and timber workers towards statement S8-D3 'Among the charcoal and pole workers, only tree cutters earn more than minimum wage'.

Service providers are not regulated by the Forest Department, and their income it is out of the hands of the current managers of the reserve. This is not the case of charcoal workers, who are employees of charcoal factories. Our study suggests that the concession agreement between charcoal factories and the Forestry Department, should be extended beyond the charcoal extraction, including a regulation policy regarding the working conditions of charcoal and timber workers. Ensuring that all workers are under the Malaysian employment and labour law Employment Act 1955, respecting their minimum working rights and improving their well-being.

Biodiversity conservation is a not stated objective of the current management of MMFR, yet, the working plan for the MMFR reported the richness and diversity of the bird community, and the relevance of MMFR for supporting migratory birds (Ariffin and Nik Mohd Shah, 2013; Latiff and Faridah-Hanum, 2014, 2014). However, there is no monitoring system for bird populations established in MMFR, for example. 

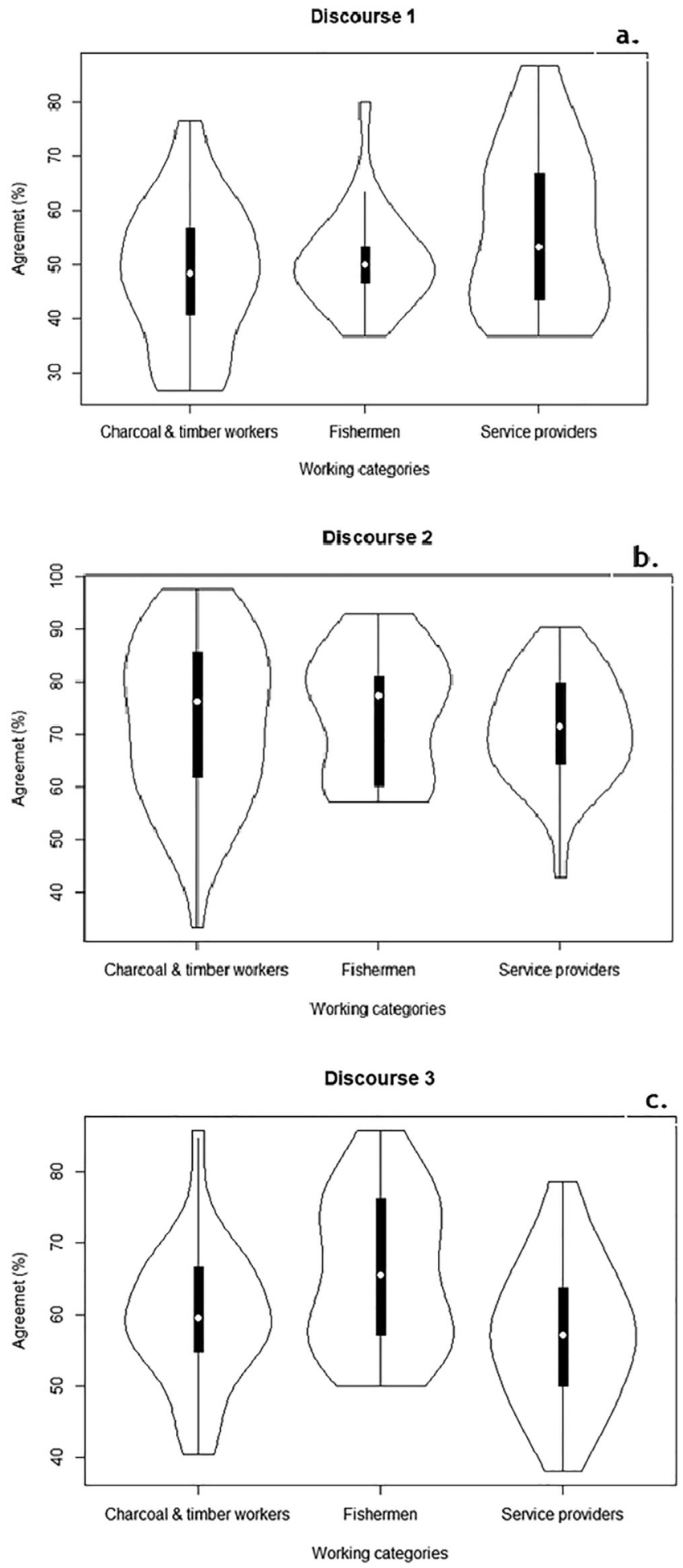

Fig. 7. Density plots illustrating the different distribution of agreement per discourse among working categories. White points denote group means, and the whiskers extend until the lowest/highest value within 1.5 IQR of the lower/ upper quartile, the shape around the boxplots represent the kernel density to show the distribution shape of the data. Wider sections of the density plot represent a higher probability that a person of each category will take on the given value; the skinnier sections represent a lower probability. Discourse 1 (7a), Charcoal Workers (CW) $\left(\mu=0.71, \sigma^{2}=0.01\right)$, Fishermen $(\mathbf{F})(\mu=0.50$, $\left.\sigma^{2}=0.008\right)$ and Service providers (SP) $\left(\mu=0.48, \sigma^{2}=0.17\right)$. Discourse 2 (7b) CW ( $\left.\mu=0.71, \sigma^{2}=0.01\right), \mathbf{F}\left(\mu=0.73, \sigma^{2}=0.01\right)$, SP $(\mu=0.71$, $\left.\sigma^{2}=0.01\right)$. Discourse $3(7 \mathrm{c})$ CW $\left(\mu=0.59, \sigma^{2}=0.009\right), \mathbf{F}(\mu=0.65$, $\left.\sigma^{2}=0.01\right)$, SP $\left(\mu=0.57, \sigma^{2}=0.009\right)$.

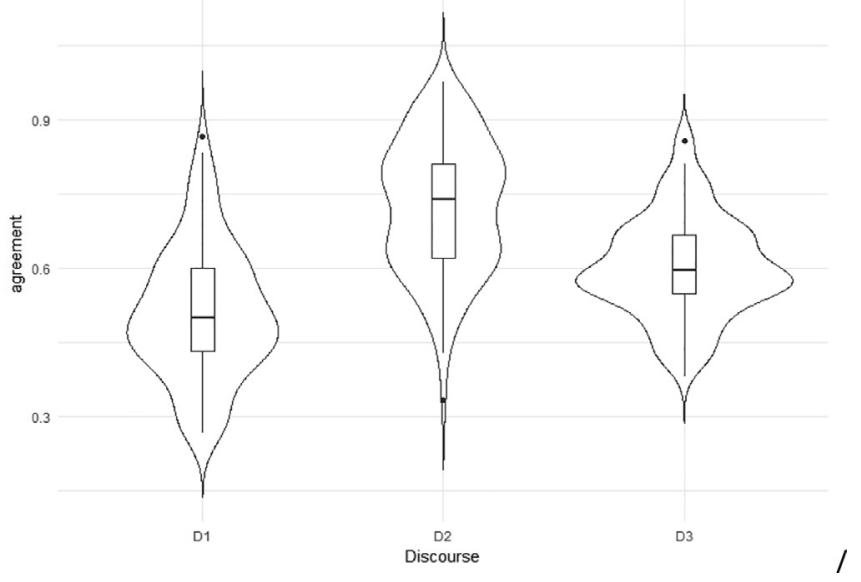

Fig. 8. Boxplot with kernel density illustrating the total difference in the distribution of agreement per discourse. D1 $\mu=50.81, \sigma_{\overline{\mathrm{x}}}=1.25,1.5$ $\mathrm{IQR}=48.31,53.33, \mathrm{D} 2 \mu=72.49, \sigma_{\mathrm{x}}=1.26,1.5 \mathrm{IQR}=69.98,75.01, \mathrm{D} 3$ $\mu=60.19, \sigma_{\overline{\mathrm{x}}}=0.95,1.5 \mathrm{IQR}=58.28,62.10$.

Our study showed that local stakeholders have knowledge about biodiversity issues in MMFR, e.g. fishermen were the only category to agree with statement S14-D3 (bird population decline). This result only reflects the perception of the people and does not necessarily align with field evidence, although, it can be considered as an indicator (Bennett, 2016). So far, the only study in bird population, was carried out by Sleutel (2016), performing a preliminary assessment of the impact of the current silvicultural management practices on avifauna communities in MMFR. This assessment reported changes in the avifaunal communities due to habitat degradation and forest fragmentation. In this case, the result of fishermen perceptions is in alignment with the results of Sleutel (2016). The combination of both provides supportive evidence for development and implementation of a suitable monitoring system lead by experts, and involve local stakeholders (citizen science opportunities). This monitoring program could gather information to validate the presence of vulnerable or endangered species according to the IUCN Red List (IUCN, 2001), and could also be valuable information to promote MMFR as a migratory species refuge (Navid, 1989). A solid scientific monitoring of the fauna of MMFR is currently scarce. Instauration of diverse faunal monitoring programs carried out by local stakeholders as a remunerated activity to gather evidence of presence and abundance of the different species is needed to valorise the structural ecosystem services, then quantify the importance of the reserve (Kerr et al., 2008) and could bring alternative income sources to local stakeholders.

The threats to the reserve's ecosystem services such as water pollution and deforestation have to be quantified. The statements related to these matters capture knowledge about these extensive problems, which are not directly related to charcoal production, but which are still useful to the ecosystem managers (Olsson and Folke, 2001). The resulting perception study reports a strong disagreement regarding the statement 'Water in Matang mangroves is polluted due to industrial activities, palm oil mills and rubber factories inland'. MMFR is surrounded by palm plantations. Therefore, it is likely to be affected by potential pollutants of the palm oil mill effluent i.e. fertilisers, insecticides, rodenticides and herbicides (Corley and Tinker, 2008; Wood and Fee, 2003), but such impacts have not been assessed or monitored in MMFR. Nonetheless, palm oil plantations represent one of the main threats to the reduction of the reserve area through land encroachment (Fitzherbert et al., 2008; Ibharim et al., 2015; Richards and Friess, 2016) or through the disturbance of fauna in the existent reserve (Sulai et al., 2015).

Statement D2-S3- 'Mangroves are most important because they provide a carbon/CO2 sink (they store carbon and hence they are important in 

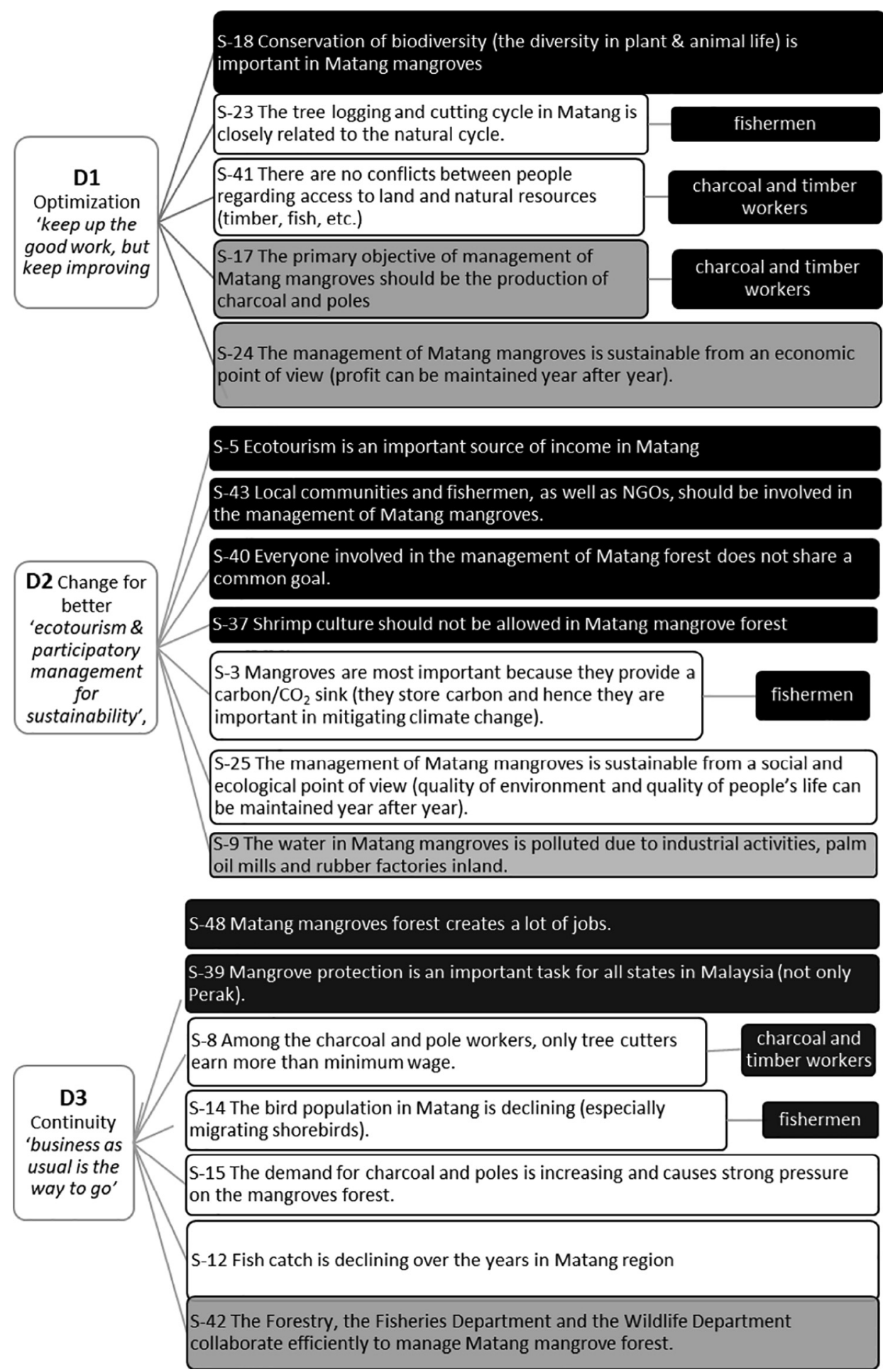

Fig. 9. Results of statements that were used to detect participants' perception (support or rejection) towards the three discourses identify by Hugé et al., (2016). Statements with support of $>50 \%$ of the participants (black), no support or rejection (white), with partial support ( $>50 \%$ ) from a specific professional category (black) and general rejection (grey) are shown.

mitigating climate change', did not obtain any conclusive result. This could suggest that the local people are not aware of the role of the mangrove forest as a carbon sink. Besides, it is possible that this statement contained too many technical concepts (carbon sinks or climate change) that were explained in the interview, but were still not clear for the participants. Even so, the concept of carbon-based incentives for environmental services to mitigate climate change is popular among forest reserves managers, and MMFR demonstrates an attractive area for a blue carbon-based REDD + (Reducing Emissions from Deforestation and Forest Degradation Plus) pilot project (Ammar et al., 2014).

The lack of awareness regarding water quality issues, and regarding the role of MMFR as a carbon sink opens an opportunity to promote environmental education programs directed to local stakeholders, and close this knowledge gap. Stakeholders' working category influences the perception of the impact of current charcoal extraction. 
The results of statements related to mangrove protection (S18-D1, S37-D2, S39-D3) from the three discourses, were supported by most stakeholders. This is a major achievement and seems to reflect a more positive image of the mangrove than in surrounding regions and countries (e.g. in Indonesia, where mangrove forests are being drained or converted to aquaculture ponds (van Oudenhoven et al., 2015)).

The perception of the local stakeholders is hopeful, especially in the light of the current trend of mangrove loss worldwide. Here in Matang, the local stakeholders support the conservation of the forest and agreed with the current mangrove forest management's effort to maintain the mangrove cover (Ariffin and Nik Mohd Shah, 2013). Additionally, Malaysian forest policy seems to be more supportive towards mangrove protection than other southeast Asian countries' policies (Jusoff and Taha, 2008b).

These local circumstances are key to improve the current mangrove management. The results of our study point to the willingness of stakeholders to move towards a more collaborative management. Subsequently, an inclusive and balanced institutional framework with a stronger multi-actor governance system (including scientists, government officials, local community representatives) that delivers holistic policies that acknowledge the interests of the local inhabitants needs to be promoted. In doing so a more sustainable management of the MMFR will be promoted.

Current global trends of unsustainable forest management and declining ecosystem services may be countered by delving into success stories such as the collaborative management of MMFR, which could be maintained by its local population.

\section{Conclusion}

By measuring the approval rate of various mangrove management discourses, this study identifies and describes the preferences of local stakeholders regarding mangrove management in the Matang area in Malaysia and the opportunities for improvement.

The analysis highlights that the local stakeholders do not perceive major changes in ecosystem functionality nor in ecosystem services provision, even though some scientific studies point at a (slight) decrease in forest cover, a decrease in bird populations and a water pollution problem. Hence it appears that there is at least a partial mismatch between stated stakeholders' opinions and existing scientific studies. A stronger co-production of knowledge between scientists and local stakeholders in future research, could contribute to address this gap.

Local stakeholders are aware that the forest provides charcoal and timber, but are not aware about other ecosystem services like carbon storage, the interdependence with marine ecosystems and coastal protection. Nonetheless, all agree to protect the forest, they acknowledge the richness and want to maintain the forest as a natural resource provider. The stakeholders highly disagreed on cutting down the forest and replacing it by other kind of land use, i.e. shrimp farming. Expanding the knowledge of people regarding other ecosystem services -and their economic value- will likely lead to a more multidimensional sustainable management of the mangrove, a change that most stakeholders call for, as indicated by their support for the incremental 'change for the better' discourse.

Differences in perspectives related to social and economic aspects (access to land and natural resources conflicts, differences in wages, and primary objective of management) emerge among the interviewed stakeholders, which points at the uneven working conditions and uneven quality of life. The differences among working categories reflect that a single-use management objective (focusing almost exclusively on charcoal and timber production) is dividing the population. The working conditions of charcoal and timber workers ideally need to be improved, and a stronger inclusion of stakeholders such as fishermen in the set-up of the management plans is advised.

The fact that Discourse 2 'Change for the better' was the most popular, regardless of stakeholders' professional background, is key. It suggests that the local stakeholders have a rather consensual view on the need for an incremental change of the current mangrove management system. They mostly support the diversification of mangrovebased economic activities (which are now mostly based on charcoal and timber production), and they show strong support for the maintenance of the forest.

The insights of this study could guide the current actors to implement changes in the current policies and management that promote more sustainable and diversified livelihoods for the local people while maintaining the ecosystem's functionality and biodiversity with the support of the local stakeholders. The lack of strong polarization regarding future mangrove management in Matang is a window of opportunity that needs to be seized to work on incremental, broadly supported change towards even more sustainable management of the world's longest formally managed mangrove forest.

\section{Declaration of Competing Interest}

The authors declare that they have no known competing financial interests or personal relationships that could have appeared to influence the work reported in this paper.

\section{Acknowledgments}

We would like to thank Nur Syahirah Mohd Radzi and Lee Soon Siong and Chua Yee Ling for their field assistance and language translation Malay-English and Chinese-English during the fieldwork.

We thank the Forestry Department Malaysia and State Forestry Department of Perak for granting their permission to work at Kuala Sepetang.

We thank Kuala Sepetang's community for participating in this survey and Mr. Kamal's family who provided us local hospitality. Terima kasih atas sambutan yang mesra, 感谢你热情的欢迎.

We acknowledge the Matang Mangrove Forest Reserve ranger team, in particular, ranger Pak Abu for the logistic support provided.

We thank Beth Turner and Lucy Van Dieijen for proofreading and Juan Luis Lechuga Crespo, for his ideas concerning data treatment.

\section{Funding}

An Erasmus Mundus TROPIMUNDO MSc thesis scholarship provided the financial needs to complete the present study.

\section{Appendix A. Supplementary data}

Supplementary data to this article can be found online at https:// doi.org/10.1016/j.foreco.2019.117741.

\section{References}

Addams, H., Proops, J.L., 2000. Social discourse and environmental policy: an application of Q methodology. Edward Elgar Publishing.

Adeel, Z., Pomeroy, R., 2002. Assessment and management of mangrove ecosystems in developing countries. Trees 16, 235-238. https://doi.org/10.1007/s00468-0020168-4.

Ahmad, S., 2009. Recreational values of mangrove forest in Larut Matang Perak. J. Trop. For. Sci. 21, 81-87.

Amir, A.A., 2012. Canopy gaps and the natural regeneration of Matang mangroves. For. Ecol. Manag. 269, 60-67. https://doi.org/10.1016/j.foreco.2011.12.040.

Ammar, A., Dargusch, P., Shamsudin, I., 2014. Can the Matang mangrove forest reserve provide perfect teething ground for a blue carbon based REDD + PILOT project? J. Trop. For. Sci. 26, 371-381.

Andaya, B.W., Andaya, L.Y., 2016. A history of Malaysia. Macmillan International Higher Education.

Appeltans, W., Ahyong, S.T., Anderson, G., Angel, M.V., Artois, T., Bailly, N., Bamber, R., Barber, A., Bartsch, I., Berta, A., Błażewicz-Paszkowycz, M., Bock, P., Boxshall, G., Boyko, C.B., Brandão, S.N., Bray, R.A., Bruce, N.L., Cairns, S.D., Chan, T.-Y., Cheng, L., Collins, A.G., Cribb, T., Curini-Galletti, M., Dahdouh-Guebas, F., Davie, P.J.F., Dawson, M.N., De Clerck, O., Decock, W., De Grave, S., de Voogd, N.J., Domning, 
D.P., Emig, C.C., Erséus, C., Eschmeyer, W., Fauchald, K., Fautin, D.G., Feist, S.W., Fransen, C.H.J.M., Furuya, H., Garcia-Alvarez, O., Gerken, S., Gibson, D., Gittenberger, A., Gofas, S., Gómez-Daglio, L., Gordon, D.P., Guiry, M.D., Hernandez, F., Hoeksema, B.W., Hopcroft, R.R., Jaume, D., Kirk, P., Koedam, N., Koenemann, S., Kolb, J.B., Kristensen, R.M., Kroh, A., Lambert, G., Lazarus, D.B., Lemaitre, R., Longshaw, M., Lowry, J., Macpherson, E., Madin, L.P., Mah, C., Mapstone, G., McLaughlin, P.A., Mees, J., Meland, K., Messing, C.G., Mills, C.E., Molodtsova, T.N., Mooi, R., Neuhaus, B., Ng, P.K.L., Nielsen, C., Norenburg, J., Opresko, D.M., Osawa, M., Paulay, G., Perrin, W., Pilger, J.F., Poore, G.C.B., Pugh, P., Read, G.B., Reimer, J.D., Rius, M., Rocha, R.M., Saiz-Salinas, J.I., Scarabino, V., Schierwater, B., SchmidtRhaesa, A., Schnabel, K.E., Schotte, M., Schuchert, P., Schwabe, E., Segers, H., SelfSullivan, C., Shenkar, N., Siegel, V., Sterrer, W., Stöhr, S., Swalla, B., Tasker, M.L., Thuesen, E.V., Timm, T., Todaro, M.A., Turon, X., Tyler, S., Uetz, P., van der Land, J., Vanhoorne, B., van Ofwegen, L.P., van Soest, R.W.M., Vanaverbeke, J., WalkerSmith, G., Walter, T.C., Warren, A., Williams, G.C., Wilson, S.P., Costello, M.J., 2012. The magnitude of global marine species diversity. Curr. Biol. 22, 2189-2202. https:// doi.org/10.1016/j.cub.2012.09.036.

R. Ariffin Nik Mohd Shah N.M., A working plan for the Matang Mangrove Forest Reserve, Perak: sixth revision of the first 10-year period (2010-2019) of the third rotation 2013 State For. Dep Perak Perak 229.

Barbier, E.B., Hacker, S.D., Kennedy, C., Koch, E.W., Stier, A.C., Silliman, B.R., 2011. The value of estuarine and coastal ecosystem services. Ecol. Monogr. 81, 169-193. https://doi.org/10.1890/10-1510.1.

Barry, J., Proops, J., 1991. Seeking sustainability discourses with Q methodology. Ecol. Econ. 28 (3), 337-345. https://doi.org/10.1016/S0921-8009(98)00053-6.

Bennett, N.J., 2016. Using perceptions as evidence to improve conservation and environmental management: Perceptions and Conservation. Conserv. Biol. 30, 582-592. https://doi.org/10.1111/cobi.12681.

Berkes, F., Folke, C., Colding, J., 2000. Linking Social and Ecological Systems: Management Practices and Social Mechanisms for Building Resilience. Cambridge University Press.

Blasco, F., Aizpuru, M., Gers, C., 2001. Depletion of the mangroves of Continental Asia. Wetl. Ecol. Manag. 9, 255-266. https://doi.org/10.1023/A:1011169025815.

Clough, B.F., 1993. Status and value of mangrove forests.

Cochran, W.G., 1977. Sampling Techniques, 3d Ed. Wiley, New York.

Cohen, D.J., Cohen, J., 2006. The sectioned density plot. Am. Stat. 60, 167-174.

Converse, J.M., Presser, S., 1986. Survey Questions: Handcrafting the Standardized Questionnaire. Sage.

Corley, R.H.V., Tinker, P.B., 2008. The Oil Palm. John Wiley \& Sons.

Dahdouh-Guebas, F., Jayatissa, L.P., Di Nitto, D., Bosire, J.O., Lo Seen, D., Koedam, N., 2005. How effective were mangroves as a defence against the recent tsunami? Curr. Biol. 15, R443-R447. https://doi.org/10.1016/j.cub.2005.06.008.

Danielson, S., 2009. Q method and surveys: three ways to combine Q and R. Field Methods 21, 219-237. https://doi.org/10.1177/1525822X09332082.

Davis, P.J., Rabinowitz, P., 2007. Methods of Numerical Integration. Courier Corporation.

Donato, D.C., Kauffman, J.B., Murdiyarso, D., Kurnianto, S., Stidham, M., Kanninen, M., 2011. Mangroves among the most carbon-rich forests in the tropics. Nat. Geosci. 4, 293-297. https://doi.org/10.1038/ngeo1123.

Duke, N.C., Meynecke, J.-O., Dittmann, S., Ellison, A.M., Anger, K., Berger, U., Cannicci, S., Diele, K., Ewel, K.C., Field, C.D., Koedam, N., Lee, S.Y., Marchand, C., Nordhaus, I., Dahdouh-Guebas, F., 2007. A world without mangroves? Science 317, 41b-42b. https://doi.org/10.1126/science.317.5834.41b.

Ellison, A.M., 2008. Managing mangroves with benthic biodiversity in mind: Moving beyond roving banditry. J. Sea Res. 59, 2-15. https://doi.org/10.1016/j.seares.2007. 05.003.

Ewel, K., Twilley, R., Ong, J.I.N., 1998. Different kinds of mangrove forests provide different goods and services. Glob. Ecol. Biogeogr. Lett. 7, 83-94.

Feagin, R.A., Mukherjee, N., Shanker, K., Baird, A.H., Cinner, J., Kerr, A.M., Koedam, N., Sridhar, A., Arthur, R., Jayatissa, L.P., Lo Seen, D., Menon, M., Rodriguez, S., Shamsuddoha, M., Dahdouh-Guebas, F., 2010. Shelter from the storm? Use and misuse of coastal vegetation bioshields for managing natural disasters. Conserv. Lett. 3, 1-11. https://doi.org/10.1111/j.1755-263X.2009.00087.x.

Fitzherbert, E., Struebig, M., Morel, A., Danielsen, F., Bruhl, C., Donald, P., Phalan, B., 2008. How will oil palm expansion affect biodiversity? Trends Ecol Evol. 23, 538-545. https://doi.org/10.1016/j.tree.2008.06.012.

Folke, C., Hahn, T., Olsson, P., Norberg, J., 2005. Adaptive governance of social-ecological systems. Annu. Rev. Environ. Resour. 30, 441-473. https://doi.org/10.1146/ annurev.energy.30.050504.144511.

Ghazoul, J., 2007. Recognising the complexities of ecosystem management and the ecosystem service concept. Gaia-Ecol. Perspect. Sci. Soc. 16, 215-221.

Giri, C., Ochieng, E., Tieszen, L.L., Zhu, Z., Singh, A., Loveland, T., Masek, J., Duke, N., 2011. Status and distribution of mangrove forests of the world using earth observation satellite data: Status and distributions of global mangroves. Glob. Ecol. Biogeogr. 20, 154-159. https://doi.org/10.1111/j.1466-8238.2010.00584.x.

Glaser, M., Krause, G., Oliveira, R.S., Fontalvo-Herazo, M., 2010. Mangroves and People: A Social-Ecological System. In: Saint-Paul, U., Schneider, H. (Eds.), Mangrove Dynamics and Management in North Brazil. Springer, Berlin, Heidelberg, pp. 307-351. https://doi.org/10.1007/978-3-642-13457-9_21.

Goessens, A., Satyanarayana, B., Van der Stocken, T., Quispe Zuniga, M., Mohd-Lokman, H., Sulong, I., Dahdouh-Guebas, F., 2014. Is Matang Mangrove Forest in Malaysia Sustainably Rejuvenating after More than a Century of Conservation and Harvesting Management? PLoS One 9, e105069. https://doi.org/10.1371/journal.pone. 0105069.

Hamilton, S.E., Casey, D., 2016. Creation of a high spatio-temporal resolution global database of continuous mangrove forest cover for the 21st century (CGMFC-21): CGMFC-21. Glob. Ecol. Biogeogr. 25, 729-738. https://doi.org/10.1111/geb.12449.
Hugé, J., Vande Velde, K., Benitez-Capistros, F., Japay, J.H., Satyanarayana, B., Nazrin Ishak, M., Quispe-Zuniga, M., Mohd Lokman, B.H., Sulong, I., Koedam, N., DahdouhGuebas, F., 2016. Mapping discourses using Q methodology in Matang Mangrove Forest, Malaysia. J. Environ. Manage. 183, 988-997. https://doi.org/10.1016/j. jenvman.2016.09.046.

Ibharim, N.A., Mustapha, M.A., Lihan, T., Mazlan, A.G., 2015. Mapping mangrove changes in the Matang Mangrove Forest using multi temporal satellite imageries. Ocean Coast. Manag. 114, 64-76. https://doi.org/10.1016/j.ocecoaman.2015.06. 005 .

IUCN, 2001. IUCN Red List categories and criteria: Version 3.1. Species Survuval Commission. IUCN.

Jabar, B.B., Marzuki, M.B., Kamaludin, K.B., 2014. Investigation of the landscape change in old Malaysian Railway: Special references to Port Weld-Taiping Railway. Soc. Sci. 9, 357-361.

Jusoff, K., Taha, D., 2008a. Sustainable forest management practices and environmental protection in Malaysia. WSEAS Trans. Environ. Dev. 4, 191-199.

Jusoff, K., Taha, D., 2008b. Managing sustainable mangrove forests in Peninsular Malaysia. J. Sustain. Dev. 1, 88-96.

Kerr, J.T., Sugar, A., Packer, L., 2008. Indicator Taxa, rapid biodiversity assessment, and nestedness in an endangered ecosystem. Conserv. Biol. 14, 1726-1734. https://doi. $\operatorname{org} / 10.1111 / \mathrm{j} .1523-1739.2000 .99275 . x$.

Khoon, G.W., Eong, O.J., 1995. The use of demographic studies in mangrove silviculture. Asia-Pacific Symposium on Mangrove Ecosystems. Springer 255-261.

Kiso, K., Mahyam, M.-I., 2003. Distribution and feeding habits of juvenile and young John's snapper Lutjanus johnii in the Matang mangrove estuary, west coast of Peninsular Malaysia. Fish. Sci. 69, 563-568. https://doi.org/10.1046/j.1444-2906. 2003.00657.x.

Kitchenham, B., Pfleeger, S.L., 2002. Principles of survey research: part 5: populations and samples. ACM SIGSOFT Softw. Eng. Notes 27, 17. https://doi.org/10.1145/ 571681.571686.

Kosuge, T., 2001. Brief assessment of stock of mud crabs Scylla spp. in matang mangrove forest, Malaysia and proposal for resources management. Jpn. Agric. Res. Q. JARQ 35, 145-148. https://doi.org/10.6090/jarq.35.145.

Kruskal, W.H., Wallis, W.A., 1952. Use of ranks in one-criterion variance analysis. J. Am. Stat. Assoc. 47, 583-621.

Latiff, A., Faridah-Hanum, I., 2014. Mangrove ecosystem of Malaysia: status, challenges and management strategies. Mangrove Ecosystems of Asia. Springer 1-22.

Lee, S.Y., Primavera, J.H., Dahdouh-Guebas, F., McKee, K., Bosire, J.O., Cannicci, S., Diele, K., Fromard, F., Koedam, N., Marchand, C., Mendelssohn, I., Mukherjee, N., Record, S., 2014. Ecological role and services of tropical mangrove ecosystems: a reassessment: Reassessment of mangrove ecosystem services. Glob. Ecol. Biogeogr. 23, 726-743. https://doi.org/10.1111/geb.12155.

Loyau, A., Schmeller, D.S., 2017. Positive sentiment and knowledge increase tolerance towards conservation actions. Biodivers. Conserv. 26, 461-478. https://doi.org/10. 1007/s10531-016-1253-0.

Mace, G.M., 2014. Whose conservation? Science 345, 1558-1560. https://doi.org/10. $1126 /$ science. 1254704 .

Marshall, M.N., 1996. Sampling for qualitative research. Fam. Pract. 13, 522-526. https://doi.org/10.1093/fampra/13.6.522.

Mukherjee, N., Sutherland, W.J., Dicks, L., Hugé, J., Koedam, N., Dahdouh-Guebas, F., 2014a. Ecosystem service valuations of mangrove ecosystems to inform decision making and future valuation exercises. PLoS One 9, e107706. https://doi.org/10. 1371/journal.pone.0107706.

N. Mukherjee W.J. Sutherland M.N.I. Khan U. Berger N. Schmitz F. Dahdouh-Guebas N. Koedam Using expert knowledge and modeling to define mangrove composition, functioning, and threats and estimate time frame for recovery 2014 Evol. n/a-n/a Ecol 10.1002/ece3.1085.

Mukherjee, N., Zabala, A., Huge, J., Nyumba, T.O., Adem Esmail, B., Sutherland, W.J., 2018. Comparison of techniques for eliciting views and judgements in decisionmaking. Methods Ecol. Evol. 9, 54-63. https://doi.org/10.1111/2041-210X.12940.

P.J. Mumby A.J. Edwards J. Ernesto Arias-González K.C. Lindeman P.G. Blackwell A. Gall M.I. Gorczynska A.R. Harborne C.L. Pescod H. Renken C.C. Wabnitz C., Llewellyn, G., Mangroves enhance the biomass of coral reef fish communities in the Caribbean Nature 4272004533536 10.1038/nature02286.

Nagelkerken, I., Blaber, S.J.M., Bouillon, S., Green, P., Haywood, M., Kirton, L.G., Meynecke, J.-O., Pawlik, J., Penrose, H.M., Sasekumar, A., Somerfield, P.J., 2008. The habitat function of mangroves for terrestrial and marine fauna: A review. Aquat. Bot. 89, 155-185. https://doi.org/10.1016/j.aquabot.2007.12.007.

Navid, D., 1989. The international law of migratory species: the Ramsar Convention. Nat Resour. J 29, 1001

Nfotabong- Atheull, A., Din, N., Longonje, S.N., Koedam, N., Dahdouh-Guebas, F., 2009. Commercial activities and subsistence utilization of mangrove forests around the Wouri estuary and the Douala-Edea reserve (Cameroon). J. Ethnobiol. Ethnomedicine 5, 35. https://doi.org/10.1186/1746-4269-5-35.

Nuruddin, A.A., Fong, U.C., 1994. Biosocioeconomics of fishing for shrimp in Kuala Sepetang. Bay of Bengal Programme, Malaysia.

Olsson, P., Folke, C., 2001. Local ecological knowledge and institutional dynamics for ecosystem management: a study of lake Racken Watershed, Sweden. Ecosystems 4, 85-104. https://doi.org/10.1007/s100210000061.

Ostrom, E., 2009. A general framework for analyzing sustainability of social-ecological systems. Science 325, 419-422. https://doi.org/10.1126/science.1172133.

Othman, J., Bennett, J., Blamey, R., 2004. Environmental values and resource management options: a choice modelling experience in Malaysia. Environ. Dev. Econ. 9, 803-824. https://doi.org/10.1017/S1355770X04001718.

Perak Government, 2014. Population and demographics statistics, Malaysia, MAMPU [WWW Document]. URL http://www.data.gov.my/data/ms_MY/dataset/population- 
and-demographic-statistics-malaysia (accessed 2.4.19).

Quispe Zuniga, M., 2014. Mangroves fuelling livelihoods: a socio-ecological assessment and stakeholder analysis of fuelwood production and trade in Matang Mangrove Forest Reserve, Peninsular Malaysia. (MSc. Biology (specialisation Human Ecology)). VUB, Brussel.

Rastogi, A., Hickey, G.M., Badola, R., Hussain, S.A., 2013. Diverging viewpoints on tiger conservation: A Q-method study and survey of conservation professionals in India. Biol. Conserv. 161, 182-192. https://doi.org/10.1016/j.biocon.2013.03.013.

Richards, D.R., Friess, D.A., 2016. Rates and drivers of mangrove deforestation in Southeast Asia, 2000-2012. Proc. Natl. Acad. Sci. 113, 344-349. https://doi.org/10. 1073/pnas.1510272113.

Rose, D.C., 2014. Five ways to enhance the impact of climate science. Nat. Clim. Change 4, 522-524. https://doi.org/10.1038/nclimate2270.

Santos, L.C.M., Gasalla, M.A., Dahdouh-Guebas, F., Bitencourt, M.D., 2017. Socio-ecological assessment for environmental planning in coastal fishery areas: A case study in Brazilian mangroves. Ocean Coast. Manag. 138, 60-69. https://doi.org/10.1016/j. ocecoaman.2017.01.009.

Satyanarayana, B., Mulder, S., Jayatissa, L.P., Dahdouh-Guebas, F., 2013. Are the mangroves in the Galle-Unawatuna area (Sri Lanka) at risk? A social-ecological approach involving local stakeholders for a better conservation policy. Ocean Coast. Manag. 71, 225-237. https://doi.org/10.1016/j.ocecoaman.2012.10.008.

Satyanarayana, B., Muslim, A.M., Horsali, N.A.I., Zauki, N.A.M., Otero, V., Nadzri, M.I., Ibrahim, S., Husain, M.-L., Dahdouh-Guebas, F., 2018. Status of the undisturbed mangroves at Brunei Bay, East Malaysia: a preliminary assessment based on remote sensing and ground-truth observations. PeerJ 6, e4397.

Sleutel, J., 2016. A preliminary assessment of the impact of the longtime silvicultural management practiced at the Matang mangroves on avifaunal communities. (MSc. Biologie des Organismes et Ecologie - BEVT). ULB, Bruxelles.

Spalding, M., 2010. World atlas of mangroves. Routledge.

Sulai, P., Nurhidayu, S., Aziz, N., Zakaria, M., Barclay, H., Azhar, B., 2015. Effects of water quality in oil palm production landscapes on tropical waterbirds in Peninsular Malaysia. Ecol. Res. 30, 941-949. https://doi.org/10.1007/s11284-015-1297-8.

Talbot, F.F., Wilkinson, C.C., 2001. Coral reefs, mangroves and seagrasses: A sourcebook for managers. Australian Institute of Marine Science (AIMS).

van Oudenhoven, A.P., Siahainenia, A.J., Sualia, I., Tonneijck, F.H., van der Ploeg, S., de Groot, R.S., Alkemade, R., Leemans, R., 2015. Effects of different management regimes on mangrove ecosystem services in Java. Indonesia. Ocean Coast. Manag. 116, 353-367.

Wood, B.J., Fee, C.G., 2003. A critical review of the development of rat control in Malaysian agriculture since the 1960s. Crop Prot. 22, 445-461.

Young, J.C., Rose, D.C., Mumby, H.S., Benitez-Capistros, F., Derrick, C.J., Finch, T., Garcia, C., Home, C., Marwaha, E., Morgans, C., Parkinson, S., Shah, J., Wilson, K.A., Mukherjee, N., 2018. A methodological guide to using and reporting on interviews in conservation science research. Methods Ecol. Evol. 9, 10-19. https://doi.org/10. 1111/2041-210X.12828.

Zabala, A., Sandbrook, C., Mukherjee, N., 2018. When and how to use Q methodology to understand perspectives in conservation research. Conserv. Biol. 32, 1185-1194. 